\title{
Ceramide Kinase-like Protein
}

National Cancer Institute

\section{Source}

National Cancer Institute. Ceramide Kinase-like Protein. NCI Thesaurus. Code C104124.

Ceramide kinase-like protein (558 aa, $\sim 63 \mathrm{kDa}$ ) is encoded by the human CERKL gene.

This protein plays a role in protecting cells from apoptosis in oxidative stress conditions. 